\title{
Acetic acid bacteria in grape must
}

\author{
Diana Navarro, Estibaliz Mateo, Ma Jesús Torija, Albert Mas \\ Biotecnología Enológica, Department of Bioquímica i Biotecnologia, Facultat d'Enologia, \\ Universitat Rovira i Virgili, Tarragona, Spain
}

\begin{abstract}
Acetic acid bacteria (AAB) have undergone continuous taxonomic revision, resulting in an increased number of genera and species ascribed to this group. Thus, the description of the most common AAB in grapes, must and wine has changed dramatically since the initial assessments, which were primarily based on physiological methods. In the present study, we identified the $\mathrm{AAB}$ isolated from different grape musts by sequencing the $16 \mathrm{~S}$ rRNA gene and $16 \mathrm{~S}-23 \mathrm{~S}$ rRNA gene internal transcribed spacer region. We had previously performed studies from the same winery. However, in this study we now identified AAB species that have been recently described in wines, as well as others that were identified for first time in this niche. Gluconobacter cerinus, G. japonicus, $G$. thailandicus and $G$. oxydans were previously identified as $G$. oxydans. Kozakia baliensis was also within this group. Acetobacter pasteurianus, A. cerevisiae and A. malorum were formerly grouped as Acetobacter $s p$. Many isolates previously described as $G$. oxydans or $A$. acet $i$ likely correspond to other, newly described species of the same genera.
\end{abstract}

\section{Introduction}

Acetic acid bacteria (AAB) are Gram-negative or Gram-variable, ellipsoidal or rod-shaped cells that have a strict aerobic metabolism

\footnotetext{
Correspondence: Albert Mas, Department of Bioquímica i Biotecnologia, Facultat d'Enologia, Universitat Rovira i Virgili, C/ Marcel-lí Domingo s/n. 43007 Tarragona, Spain. Tel. +34.977.558688 - Fax: +34.977.558232.

E-mail: albert.mas@urv.cat

Key words: Gluconobacter, Acetobacter, grape, wine.

Acknowledgements: this study was supported by grant AGL2010-22152-C0302 from the Ministerio de Educación y Ciencia, Spain.

Conference presentation: part of this paper was presented at the $3^{\text {rd }}$ International Conference on Acetic Acid Bacteria. Vinegar and Other products, 2012 Apr 17-20, Cordoba, Spain (http://www.uco.es/aab2012/).

Received for publication: 31 August 2012.

Revision received: 29 October 2012.

Accepted for publication: 19 November 2012.

This work is licensed under a Creative Commons Attribution 3.0 License (by-nc 3.0).

(C) Copyright D. Navarro et al., 2013

Licensee PAGEPress, Italy

Acetic Acid Bacteria 2013; 2(s1):e4

doi:10.4081/aab.2013.s1.e4
}

with oxygen as the terminal electron acceptor. ${ }^{1}$ These microorganisms have been isolated from a wide variety of substrates, such as fruits, flowers, food and fermented beverages, such as wine, vinegar, kombucha tea, and cocoa. Recently, the active search for new species has led to reorganization of the group, and at present, 13 genera and over 60 species have been described. ${ }^{2}$ These changes altered the description of the presence and possible role of different $A A B$ species in various niches, such as grape must and wines.

The traditional view of the presence of AAB in grapes and wines was established by Joyeux et al. (1984). ${ }^{3}$ The view was straightforward, with Gluconobacter oxydans as the main AAB in sugar-rich media, such as grapes or must, and Acetobacter aceti present in high-ethanol media, such as wine. When the grapes were altered, the must started fermenting and $A$. aceti became the main $\mathrm{AAB}$ species, producing sour rot. The result of AAB progression in grapes is such that $G$. oxydans produces high levels of gluconic acid, whereas $A$. aceti produces acetic acid. In wines, although $A$. aceti has been considered the main altering $\mathrm{AAB}$, later studies indicated that $A$. pasteurianus was present in altered bottled wines. ${ }^{4}$ In the new millennium, several molecular biology methods have been developed for the analysis of AAB from grapes and wines and quickly displaced classical physiological methods. Although the use of molecular biology methods in general ratified the traditional description, the first molecular studies also identified other species, such as Gluconacetobacter hansenii ${ }^{5,6}$ as well as Ga. liquefaciens. $^{5-7}$ Later, $A$. oeni was described as a new species isolated in Portuguese spoiled red wines, which was considered the main spoilage agent. ${ }^{8}$ Additional newly described species were isolated in Austrian wines (A. tropicalis), ${ }^{9}$ Chilean musts (A. cerevisiae), ${ }^{10}$ and Spanish fermented musts from the Canary Islands A. tropicalis and $A$. cerevisiae along with A. malorum, G. japonicus, and Ga. saccharivorans. ${ }^{11}$ Ga. saccharivorans was also isolated in Japanese Chardonnay must fermentation. ${ }^{12}$ Asaia siamensis has been described in Tempranillo wines during malolactic fermentation. ${ }^{13}$ Thus, the present view of $\mathrm{AAB}$ species associated with grapes, must and wines is much more complex than previously described.

During the last decade, quick and easy molecular techniques based on the phylogenetic relationships between AAB have been developed for identification and typing. Species-specific polymorphisms of both ribosomal genes and their spacers have been used for identification after polymerase chain reaction-restriction fragment length polymorphism (PCR-RFLP) techniques. ${ }^{6,14-16}$ Several PCR techniques have also been proposed for AAB typing, such as enterobacterial repetitive intergenic consensus-PCR (ERIC-PCR), ${ }^{6,17,18}$ repetitive extragenic palindromic-PCR (REP-PCR); ${ }^{7}$ (GTG) ${ }_{5}$-PCR fingerprinting, ${ }^{19}$ and random amplified polymorphic DNA-PCR (RAPD-PCR). ${ }^{4,10}$ These techniques are employed on a routine basis to group $\mathrm{AAB}$. However, to identify individual $\mathrm{AAB}$ species, phylogenetic analysis and sequencing of $16 \mathrm{~S}$ rRNA genes or 16S-23S rRNA gene internal transcribed spacer (ITS) regions have been proposed. ${ }^{11,20}$

The aim of this study was to isolate and identify AAB species from grape musts obtained in the same niche in which we had previously 
performed different ecological studies. ${ }^{7,15}$ In the previous studies, we identified only five AAB species ( $G$. oxydans, A. aceti, A. pasteurianus, $G a$. hansenii and $G a$. liquefaciens) using the $\mathrm{AAB}$ species classification existing at that time. In the present study, we use molecular methods and the new AAB species classification to evaluate whether the biodiversity present in this niche is higher than initially thought.

\section{Materials and Methods}

\section{Acetic acid bacteria isolation and identification}

Isolates were obtained from two grape musts (M1 and M2) that were a mixture of different varieties from an ampelographic collection. The must samples were plated on GY medium ( $1 \%$ yeast extract, $5 \%$ glucose, $2 \%$ agar w/v) and incubated at $28^{\circ} \mathrm{C}$. Each bacterial colony obtained was then replicated on GYC medium (1\% yeast extract, $5 \%$ glucose, $0.5 \% \mathrm{CaCO}_{3}, 2 \%$ agar w/v). Colonies that produced a clear halo on GYC medium were considered putative $\mathrm{AAB}$ and were typed and identified using molecular techniques. DNA extraction was performed using a modified version of the cetyltrimethylammonium bromide method (CTAB). ${ }^{11}$

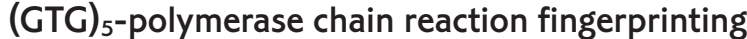

AAB genotyping was performed using (GTG) $)_{5}$-PCR fingerprinting. ${ }^{19}$ The reactions were performed using a GeneAmp PCR System 2700 (Applied Biosystems, Foster City, CA, USA). Only one primer was used (5'-GTGGTGGTGGTGGTG-3').

Amplification products were detected after electrophoresis at $80 \mathrm{~V}$ for $3 \mathrm{~h}$ on a $1.5 \%(\mathrm{w} / \mathrm{v})$ in agarose gel by staining with ethidium bromide in $1 \mathrm{X}$ TBE buffer. Pattern band lengths were determined by comparison against a DNA XVI 250 bp ladder for the largest bands and DNA XIV 100 bp ladder for the smallest bands (Roche Diagnostics, Mannheim, Germany).

16S rRNA gene and 16S-23S rRNA gene internal transcribed spacer polymerase chain reaction-restriction fragment length polymorphism and sequencing

The method used for initial identification was PCR-RFLP of the $16 \mathrm{~S}$ rRNA gene. The $16 \mathrm{~S}$ rRNA gene was amplified using the method previously described. ${ }^{15}$ The primers used were Aceti I-F (5'-GCTGGCGGCATGCTTAACACAT-3') and Aceti IV-R (5'-GGAGGTGATCCAGCCGCAGGT-3'; Invitrogen-Life Technologies, Glasgow, UK). They were designed on the basis of the conserved regions of the 5'- and 3'-end of the 16S rRNA gene. ${ }^{15}$ Amplified DNA was detected after electrophoresis at $100 \mathrm{~V}$ for 1 $\mathrm{h}$ on a $1.0 \%(\mathrm{w} / \mathrm{v})$ agarose gel by staining with ethidium bromide in $1 \mathrm{X}$ TBE buffer. The lengths of the amplified products were detected by comparison against a DNA XIV 100 bp ladder (Roche Diagnostics).

The 16S rRNA gene amplified products were digested with TaqI and AluI (Roche Diagnostics) restriction enzymes. ${ }^{15,21}$ Samples were incubated for $3 \mathrm{~h}$ at $65^{\circ} \mathrm{C}$ and $37^{\circ} \mathrm{C}$, respectively. Restriction fragments were detected after electrophoresis at $80 \mathrm{~V}$ for $3 \mathrm{~h}$ on a $2.5 \%(\mathrm{w} / \mathrm{v})$ agarose gel by staining with ethidium bromide in $1 \mathrm{X}$ TBE buffer. Band lengths were determined by comparison against a DNA XIV 100 bp ladder (Roche Diagnostics). Profiles of the obtained bands were then compared with those previously described. ${ }^{15,21}$

To confirm the identification results obtained by PCR-RFLP, representative 16S rRNA gene amplicons of each (GTG) ${ }_{5}$-PCR typing profile was sequenced by Macrogen Inc. (Seoul, South Korea) using an ABI3730xl automatic DNA sequencer. Three reactions were performed using Aceti I-F and Aceti IV-R (described above) and Aceti III-R (5'-AACCACATGCTCCACCGCTTG-3'). ${ }^{15}$
Posterior sequence merging using the CLUSTALW alignment tool (http://www.ebi.ac.uk/services/) was necessary to obtain one consensus sequence for each typing profile. The consensus sequences were compared with those in the Genbank database (http:/www.ncbi.nlm. nih.gov/genbank/).

Samples that were not identified at the species level by PCR-RFLP of the 16S rRNA gene were amplified using the 16S-23S rRNA ITS method ${ }^{16}$ using primers ITS1 (5'-ACCTGCGGCTGGATCACCTCC-3') and ITS2 (5'-CCGAATGCCCTTATCGCGCTC-3'; Invitrogen-Life Technologies). Amplified DNA was detected by electrophoresis at $100 \mathrm{~V}$ for $1 \mathrm{~h}$ on a $1.0 \%(\mathrm{w} / \mathrm{v})$ agarose gel stained with ethidium bromide in 1X TBE buffer. The lengths of the amplified products were measured by comparison against a DNA XIV 100 bp ladder (Roche Diagnostics). The amplified products were sent to Macrogen Inc. for purification and sequencing, and the sequences were analyzed as described for the $16 \mathrm{~S}$ rRNA sequences.

\section{Results and Discussion}

\section{Acetic acid bacteria isolation and identification}

Samples from two grape musts (M1 and M2) were plated on GY medium to isolate different $\mathrm{AAB}$ strains. A total of 23 isolates from M1 and 20 isolates from M2 produced a clear halo and were therefore considered putative $\mathrm{AAB}$ and typed by (GTG) $)_{5}$-PCR. Of all 43 isolates, 37 showed clear electrophoresis amplification products resulting in 21 (11 for M1 and 10 for M2) different electrophoretic profiles (Figure 1). Isolates producing distinct electrophoretic profiles were considered to be different strains.

Each profile was identified at the species level by restriction analysis of the 16S rRNA gene amplification products, and all of them presented the expected product (ca $1450 \mathrm{bp}$ ) corresponding to AAB. A comparison of restriction profiles obtained by PCR-RFLP with those obtained previously by our group, ${ }^{6,15}$ identified $4 \mathrm{AAB}$ species in M1 and 3 species in M2 (Table 1, Figure 2).

Most of the profiles (13) were grouped with $G$. oxydans PCR-RFLP electrophoretic pattern. The remaining profiles were grouped with $A$. aceti or with the species included in a cluster belonging to the Gluconacetobacter genus ( $G a$. liquefaciens, Ga.xylinus, Ga. europaeus, and $\mathrm{Ga}$. diazotrophicus). In contrast, this technique was not able to classify some profiles as known species (Table 1). Thus, these results showed the same AAB diversity previously reported in the same cellar. $6,7,15$

Although the restriction technique allows the grouping of highly related species, sequencing of the $16 \mathrm{~S}$ rRNA gene is necessary to obtain a more precise identification. The results from a comparison of the consensus sequences with the Genbank database are summarized in Table 2.

Typing profiles 1-6 and 12-18 were identified as $G$. oxydans by PCRRFLP of the $16 \mathrm{~S}$ rRNA gene; however, after sequencing, they were identified as different species belonging to the Gluconobacter genus. Only one isolate was indeed $G$. oxydans (typing profile 17); the remaining isolates belonged to closely related species: $G$. japonicus, $G$. albidus, $G$. cerinus, and $G$. thailandicus. Due to high homology between the $16 \mathrm{~S}$ rRNA genes of the AAB species, PCR-RFLP of the 16S rRNA gene was unable to differentiate between these species, and consequently, all of them were included in the same cluster. Kozakia baliensis (typing profile 12) was also included in the $G$. oxydans cluster by RFLP-PCR of the 16S rRNA gene even though it belongs to another genus. This isolate is the first Kozakia species to be described in grape must; the genus was first recovered from brown palm sugar. ${ }^{22}$

The only species accepted in the Approved List of Bacterial Names 
Table 1. Species identification by polymerase chain reaction-restriction fragment length polymorphism of the 16S rRNA gene.

\begin{tabular}{lcc} 
Typing profile & Number of isolates & Species by RFLP-PCR \\
$1,2,3,4,5,6,12,13,14,15,16,17,18$ & $12(\mathrm{M} 1) / 8(\mathrm{M} 2)$ & $\begin{array}{c}\text { Gluconobacter oxydans } \\
9,19,21\end{array}$ \\
\hline $10,11,20$ & $1(\mathrm{M} 1) / 5(\mathrm{M} 2)$ & Acetobacter aceti \\
7,8 & $2(\mathrm{M} 1) / 4(\mathrm{M} 2)$ & Unidentified \\
& $2(\mathrm{Ml})$ & $\begin{array}{c}\text { Gluconacetobacter liquefaciens, } \\
\text { Gluconacetobacter xylinus, } \\
\text { Gluconacetobacter europaeus, } \\
\text { Gluconacetobacter diazotrophicus }\end{array}$ \\
\hline
\end{tabular}

M1, M2, grape musts from which the isolates were obtained; RFLP-PCR, polymerase chain reaction-restriction fragment length polymorphism.

Table 2. Species identified by sequencing of the 16S rRNA gene and 16S-23S rRNA gene internal transcribed spacer.

\begin{tabular}{|c|c|c|c|}
\hline Grape must & Typing profile & Number of isolates & Species by sequencing \\
\hline M1 & $\begin{array}{c}1 \\
2 \\
3 \\
4 \\
5 \\
6 \\
7 \\
8 \\
9 \\
10 \\
11\end{array}$ & $\begin{array}{l}1 \\
2 \\
3 \\
1 \\
1 \\
5 \\
1 \\
1 \\
1 \\
1 \\
1\end{array}$ & $\begin{array}{c}\text { Gluconobacter cerinus } \\
\text { Gluconobacter japonicus } \\
\text { Gluconobacter cerinus } \\
\text { Gluconobacter cerinus } \\
\text {-* } \\
\text { Gluconobacter japonicus } \\
\text {-* } \\
\text {-* } \\
\text { Acetobacter malorum } \\
\text {-* } \\
\text { Acetobacter pasteurianus }\end{array}$ \\
\hline M2 & $\begin{array}{l}12 \\
13 \\
14 \\
15 \\
16 \\
17 \\
18 \\
19 \\
20 \\
21\end{array}$ & $\begin{array}{l}1 \\
1 \\
2 \\
1 \\
1\end{array}$ & $\begin{array}{c}\text { Kozakia baliensis } \\
\text { Gluconobacter japonicus } \\
\text { Gluconobacter albidus } \\
\text { Gluconobacter thailandicus } \\
\text { Gluconobacter cerinus } \\
\text { Gluconobacter oxydans } \\
\text { Kozakia baliensis } \\
\text { Acetobacter cerevisiae } \\
\text { Acetobacter sp. } \\
\text { Acetobacter } s p \text {. }\end{array}$ \\
\hline
\end{tabular}

${ }^{*}$ Typing profiles that could not be identified due to an ambiguous chromatogram.

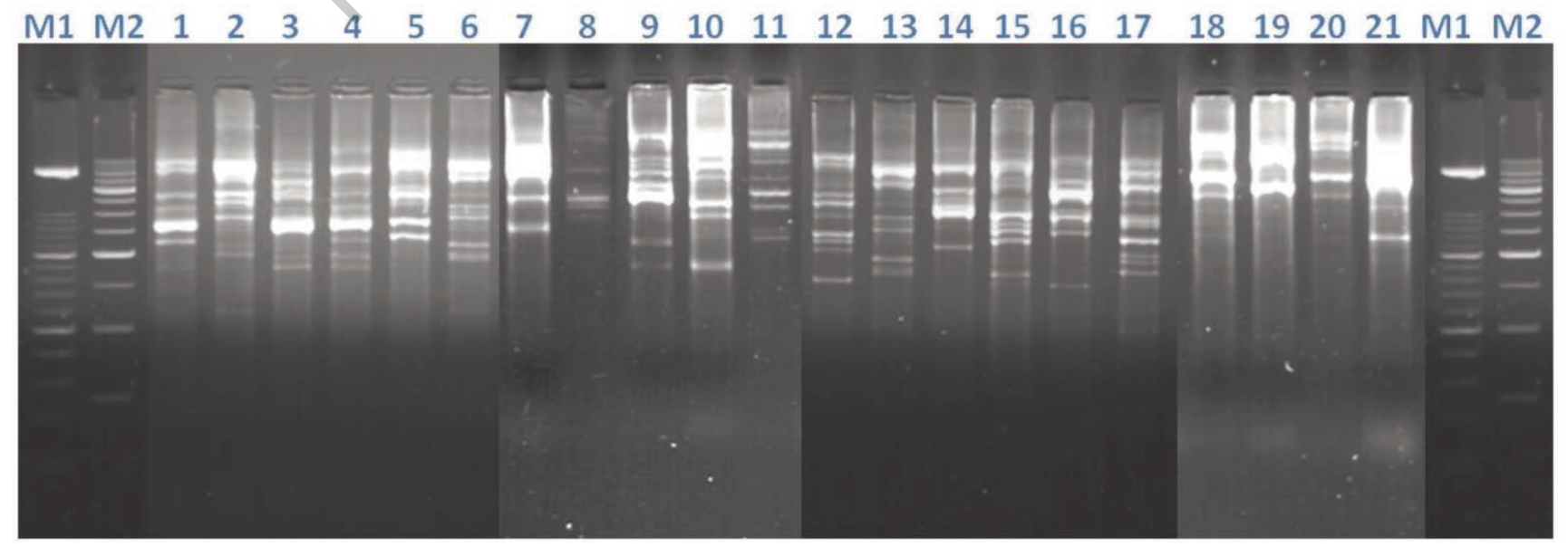

Figure 1. Different electrophoretic profiles obtained by (GTG) 5-PCR. M1: XIV 100 bp ladder. M2: XVI 250 bp ladder. 
A

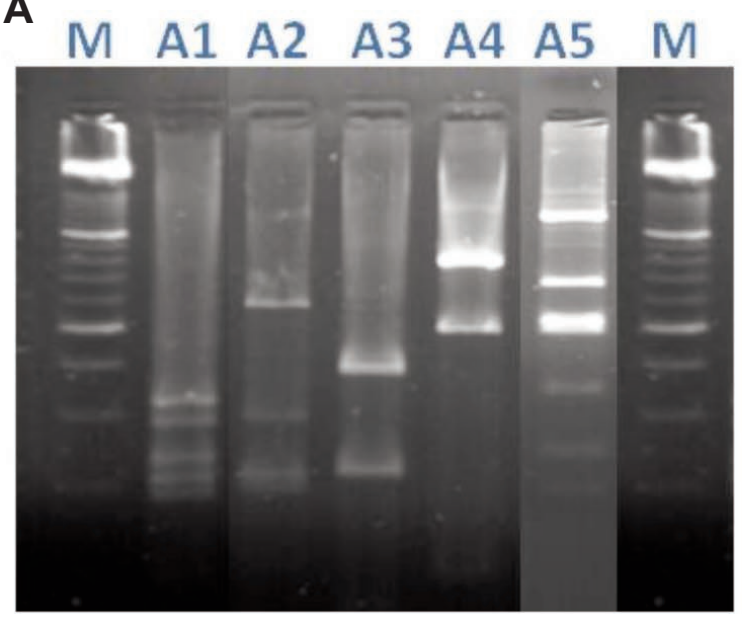

B

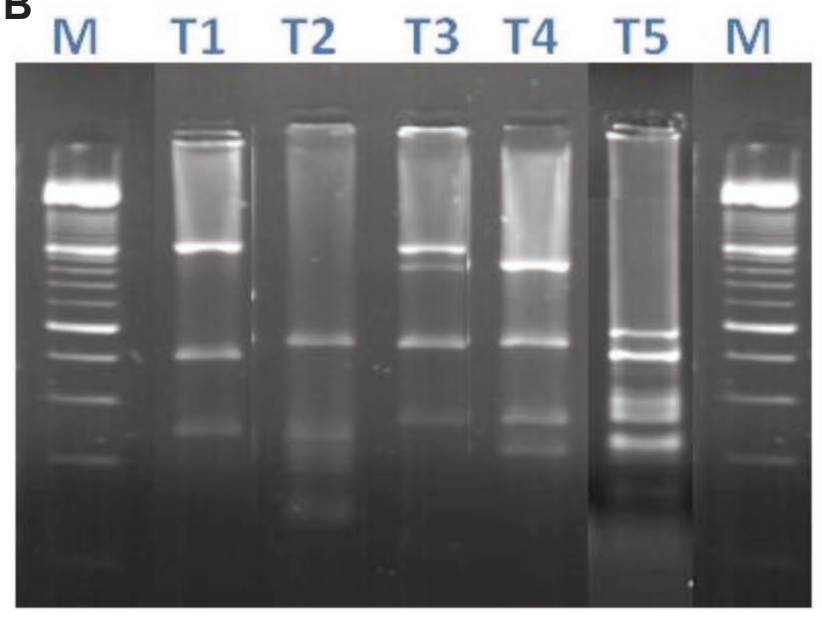

Figure 2. Electrophoretic profiles obtained by polymerase chain reaction-restriction fragment length polymorphism of the 16S rRNA gene with A) AluI and B) TaqI restriction enzymes. M: XIV 100 bp ladder. Lane A1 and T1: A. aceti; Lane A2 and T2: G. oxydans; Lane A3, A4 and T3, T4: unidentified profiles; Lane A5 and T5: Gluconacetobacter sp.

under the Gluconobacter genus before 1980 was G. oxydans. ${ }^{23}$ Since then, 13 different Gluconobacter species have been described. ${ }^{24}$ Furthermore, $G$. oxydans has been the main species associated with healthy grapes in ecological studies. ${ }^{3,5-7,10}$ Although most of these new species were isolated from sugar-rich substrates, only $G$. japonicus has also been isolated from grapes. ${ }^{11}$ The Gluconobacter species isolated from grapes in this study had initially been isolated and identified from flowers ( $G$. albidus and $G$. thailandicus) or fruits ( $G$. cerinus and $G$. japonicus). The absence of these Gluconobacter species from previous studies involving grapes is likely due to their recent discovery. Therefore, some of the isolates identified as $G$. oxydans in early ecological studies could belong to other, recently described Gluconobacter species.

Isolates corresponding to typing profiles 9 and 19 were tentatively identified by PCR-RFLP of the $16 \mathrm{~S}$ rRNA gene as A. aceti, but after $16 \mathrm{~S}$ rRNA gene sequence analysis, they were included in a cluster corresponding to the species A. malorum and A. cerevisiae. Only after sequencing of the 16S-23S rRNA gene ITS could these isolates be clearly identified as $A$. malorum (typing profile 9) and A. cerevisiae (typing profile 19). With the isolates corresponding to typing profile 11, which could not be identified by PCR-RFLP of the 16S rRNA gene, 16S rRNA gene sequencing identified this profile as A. pasteurianus or A. pomorum. Posterior identification by 16S-23S rRNA gene ITS sequence analysis identified these isolates as A. pasteurianus. The isolation of these Acetobacter species (A. malorum, A. cerevisiae, and A. pasteurianus) from grapes was not surprising because all of these species have previously been described on grapes and in wine and vinegar., ${ }^{3,4,5,10,11}$ Also identified by $16 \mathrm{~S}$ rRNA gene analysis within the Acetobacter genus were isolates with typing profiles 20 and 21 . However, no further identification could be performed beyond this point as the sequencing profiles were ambiguous, most likely due to a mixture of species in the same colony, a phenomenon which has been observed previously. The same could be true for the isolates with typing profiles 5, 7, 8 and 10, where the ambiguity in the sequence of both regions (16S rRNA gene and 16S-23S rRNA gene ITS) impeded clear identification.

\section{Conclusions}

Thus, we conclude that a high diversity of AAB species was isolated from grape must in a vineyard where previous work described a limited variability. This expansion is mostly due to the recent description of most of these species. As the number of total isolates was limited, more ecological studies should be performed to determine the actual $A A B$ diversity in grapes and wine.

\section{References}

1. De Ley J, Gillis M, Swings J. Family VI. Acetobacteraceae. In: Bergey's Manual of Systematic Bacteriology, vol. 1. Baltimore: Williams \& Wilkins; 1984.

2. Yukphan P, Malimas T, Muramatsu Y, et al. Neokomagataea gen. nov., with descriptions of Neokomagataea thailandica sp. nov. and Neokomagataea tanensis sp. nov., osmotolerant acetic acid bacteria of the -Proteobacteria. Biosci Biotechnol Biochem 2011;75:419-26.

3. Joyeux A, Lafon-Lafourcade S, Ribereau-Gayon P. Metabolism of acetic acid bacteria in grape must consequences on alcoholic and malolactic fermentation. Sci Alim 1984;4:247-55.

4. Bartowsky E, Xia D, Gibson R, et al. Spoilage of bottled red wine by acetic acid bacteria. Lett Appl Microbiol 2003;36:307-14.

5. Du Toit W, Lambrechts $M$. The enumeration and identification of acetic acid bacteria from South African red wine fermentations. Int J Food Microbiol 2002;74:57-64.

6. González A, Hierro N, Poblet M, et al. Application of molecular methods for the differentiation of acetic acid bacteria in a red wine fermentation. J Appl Microbiol 2004;96:853-60.

7. González A, Hierro N, Poblet M, et al. Application of molecular methods to demonstrate species and strain evolution of acetic acid bacteria population during a wine production. Int J Food Microbiol 2005;102:295-304. 
8. Silva LR, Cleenwerck I, Rivas R, et al. Acetobacter oeni sp. nov., isolated from spoiled red wine. Int J Syst Evol Microbiol 2006;56:21-4.

9. Silhavy K, Mandl K. Acetobacter tropicalis in spontaneously fermented wines with vinegar fermentation in Austria. Mitteilungen Klosterneuburg 2006;56:102-7.

10. Prieto C, Jara C, Mas A, Romero J. Application of molecular methods for analyzing the distribution and diversity of acetic acid bacteria in Chilean vineyards. Int J Food Microbiol 2007;115:348-55.

11. Valera MJ, Laich F, González S, et al. Diversity of acetic acid bacteria present in healthy grapes from the Canary Islands. Int J Food Microbiol 2011;151:105-12.

12. Kato $\mathrm{S}$, Ishihara $\mathrm{T}$, Hemmi $\mathrm{H}$, et al. Alterations in D-amino acid concentrations and microbial community structures during the fermentation of red and white wines. J Biosci Bioeng 2011;111:104-8.

13. Ruiz P, Seseña S, Izquierdo PM, Palop ML. Bacterial biodiversity and dynamics during malolactic fermentation of Tempranillo wines as determined by a culture-independent method (PCR-DGGE). Appl Microbiol Biotechnol 2010;86:1555-62.

14. Sievers M, Lorenzo A, Gianotti S et al. 16-23S ribosomal RNA spacer regions of Acetobacter europaeus and A. xylinum, tRNA genes and antitermination sequences. FEMS Microbiol Lett 1996;142:438 .

15. Ruiz A, Poblet M, Mas A, Guillamon JM. Identification of acetic acid bacteria by RFLP of PCR-amplified 16S rDNA and 16S-23S rDNA intergenic spacer. Int J Syst Evol Microbiol 2000;50:1981-7.

16. Gullo M, Caggia C, De Vero L, Giudici P. Characterization of acetic acid bacteria in "traditional balsamic vinegar". Int J Food Microbiol 2006;106:209-12.
17. Nanda K, Taniguchi M, Ujike S, et al. Characterization of acetic acid bacteria in traditional acetic acid fermentations of rice vinegar (Komesu) and unpolished rice vinegar (Kurosu) produced in Japan. Appl Env Microbiol 2001;67:986-90.

18. Gullo M, De Vero L, Guidici P. 2009. Succession of selected strains of Acetobacter pasteurianus and other acetic acid bacteria in traditional balsamic vinegar. Appl Env Microbiol 2009;75: 2585-9.

19. De Vuyst L, Camu N, DeWinter T, et al. Validation of the (GTG) $)_{5-}$ rep-PCR fingerprinting technique for rapid classification and identification of acetic acid bacteria, with a focus on isolates from Ghanaian fermented cocoa beans. Int J Food Microbiol 2008; 125:79-90.

20. González A, Mas A. Differentiation of acetic acid bacteria based on sequence analysis of $16 \mathrm{~S}$-23S rRNA gene internal transcribed spacer sequences. Int J Food Microbiol 2011;147:217-22.

21. González A, Guillamón JM, Mas A, Poblet M. Application of molecular methods for routine identification of acetic acid bacteria Int $\mathrm{J}$ Food Microbiol 2006;108:141-6.

22. Lisdiyanti P, Kawasaki H, Widyastuti Y, et al. Kozakia baliensis gen. nov., sp. nov., a novel acetic acid bacterium in the -Proteobacteria. Int J Syst Evol Microbiol 2002;52:813-8.

23. Yamada Y, Yukphan P. Genera and species in acetic acid bacteria. Int J Food Microbiol 2008;125: 15-24.

24. Tanasupawat S, Kommanee J, Yukphan P, et al. Gluconobacter uchimurae sp. nov., an acetic acid bacterium in the Proteobacteria. J Gen Appl Microbiol 2011;57:293-301. 